\title{
AN INVESTIGATION ON AIR AND THERMAL TRANSMISSION THROUGH KNITTED FABRIC STRUCTURES USING THE TAGUCHI METHOD
}

\author{
Anindya Ghosh¹, Prithwiraj Mal ${ }^{2}$, Abhijit Majumdar ${ }^{3}$, and Debamalya Banerjee ${ }^{4}$ \\ 1Department of Textile Technology, Government College of Engineering and Textile Technology, Berhampore 742101, India \\ ${ }^{2}$ Department of Textile Design, National Institute of Fashion Technology, Hyderabad - 500081, India, \\ Email: prithwiraj_iitd@yahoo.co.uk \\ ${ }^{3}$ Department of Textile Technology, Indian Institute of Technology, New Delhi 110016, India \\ ${ }^{4}$ Department of Production Engineering, Jadavpur University, Kolkata 700032, India
}

\begin{abstract}
:
Knitted fabrics have excellent comfort properties because of their typical porous structure. Different comfort properties of knitted fabrics such as air permeability, thermal absorptivity, and thermal conductivity depend on the properties of raw material and knitting parameters. In this paper, an investigation was done to observe the effect of yarn count, loop length, knitting speed, and yarn input tension in the presence of two uncontrollable noise factors on selected comfort properties of single jersey and $1 \times 1$ rib knitted fabrics using the Taguchi experimental design. The results show that yarn count and loop length have significant influence on the thermo-physiological comfort properties of knitted fabrics.
\end{abstract}

\section{Keywords:}

Taguchi experimental design, air permeability, thermal conductivity, thermal absorptivity, single jersey, $1 \times 1$ rib knitted fabric.

\section{Introduction}

The comfort of a fabric is characterized by several properties such as transmission of heat, water vapor and air, warm or cool feeling on touch, absorbency, and wicking. Knitted fabrics are well known for their excellent comfort properties that are facilitated by the porous structure. Air can easily pass through the interyarn pores of knitted fabrics. On the other hand, knitted fabrics can hold lot of air within the structure resulting in lower thermal conductivity and higher thermal resistance than an equivalent woven fabric. In tropical and subtropical countries, high air permeability and thermal conductivity is required, whereas for winter, low air permeability along with high thermal resistance is desired. These comfort properties are decisively influenced by the material (type of fiber, yarn linear density, etc.), structural (loop length), and process parameters (carriage speed and yarn input tension). Process parameters can actually influence the structural parameters and thereby influence the comfort properties. Therefore, it is important to understand the roles of materials and process parameters affecting the comfort properties.

Many researchers have studied the effect of raw materials and knitted fabric construction parameters on the comfort behavior of fabrics. Investigations revealed that the type of fiber, fiber blends, yarn structure and fineness, fabric structure, and different process parameters affect various comfort properties such as air permeability, moisture management, thermal conductivity, and thermal absorptivity [1-8]. Some attempts were also made by the researchers to predict and optimize different comfort properties of knitted fabrics using various techniques. Mavruz and Ogulata [9] tried to optimize air permeability of interlock knitted fabrics using different experimental designs. Fayala et al. [10] and Mitra et al. [11] predicted the thermal properties of knitted and woven fabrics, respectively, using artificial neural network. Luo et al. [12] developed a fuzzy neural-network-based model to predict clothing thermal comfort. Cubric et al. [13] investigated on the significant fabric parameters affecting the heat transfer through porous structure and concluded that the thermal resistance of single jersey knitted fabric has a strong correlation with thickness, areal density, cover factor, and porosity.

Most of the researches who worked on the comfort behavior of knitted fabrics are primarily concerned with the individual study of thermal properties or air permeability or moisture management. There is hardly any published literature that encompasses the individual as well as the interactive effect of material, structural, and process parameters on comfort properties, that is, air permeability, thermal conductivity, and thermal absorptivity. In this investigation, the Taguchi experimental design has been used to study the effects of material (yarn count), structural (loop length), and process parameters (carriage speed and yarn input tension) on air permeability, thermal conductivity, and thermal absorptivity for both single jersey and $1 \times 1$ rib knitted fabrics. Two noise parameters such as knitting position in the machine and yarn from different cones have been considered for both types of fabrics.

\section{Experimental}

\subsection{Preparation of fabric samples}

One hundred percent cotton ring spun yarns of three different counts (such as $5,7.5$, and $10 \mathrm{Ne}$ ) were used to make both 
single jersey and $1 \times 1$ rib knitted fabrics. All the yarn types used in the experimentation are combed and have same twist multiplier (TM) of 3.42 (TM = TPI / Vyarn count). The yarn fineness of all three types of yarns were measured. For each yarn type, two cones were taken, and totally 10 readings are taken ( 5 readings from each cone) to calculate the actual yarn count. For each reading, 120 yards of yarn were tested for yarn count. The average of 10 readings were considered and compared with the set value. The error was found to be less than $1.2 \%$. Four controlled factors such as loop length, carriage speed, yarn input tension, and yarn count were chosen, and for each factor, three levels were considered. All the fabric samples were made in a 12-gauge (number of needles in 1 inch width of the machine) computerized flat knitting machine equipped with "digital stitch control system" to control the loop length at desired level. Two noise factors such as fabric production from two different cones and two sides of the machine (right side and left side) were considered in this study. Both single jersey and $1 \times 1$ rib knitted fabrics samples were prepared according to the L9 orthogonal array as shown in Table 1. The controlled factors $X_{1}, X_{2}, X_{3}$, and $X_{4}$ correspond to loop length, carriage speed, yarn input tension, and yarn count, respectively. Two noise factors at two different levels put together four repetitions for each of the nine experimental run. Therefore, the total number of samples was $9 \times 4=36$, each for single jersey and $1 \times 1$ rib knitted fabrics. Tables 2 and 3 show the actual values of controlled and noise factors corresponding to their coded levels.

Table 1. L9 $\left(3^{4}\right)$ orthogonal array

\begin{tabular}{|c|c|c|c|c|c|c|}
\hline \multirow{2}{*}{$\begin{array}{l}\text { Experimental } \\
\text { run }\end{array}$} & \multicolumn{4}{|c|}{ Controlled factors } & \multicolumn{2}{|c|}{ Noise factors } \\
\hline & $X_{1}$ & $X_{2}$ & $X_{3}$ & $X_{4}$ & Cone & Machine side \\
\hline 1 & 1 & 1 & 1 & 1 & \pm 1 & \pm 1 \\
\hline 2 & 1 & 2 & 2 & 2 & \pm 1 & \pm 1 \\
\hline 3 & 1 & 3 & 3 & 3 & \pm 1 & \pm 1 \\
\hline 4 & 2 & 1 & 2 & 3 & \pm 1 & \pm 1 \\
\hline 5 & 2 & 2 & 3 & 1 & \pm 1 & \pm 1 \\
\hline 6 & 2 & 3 & 1 & 2 & \pm 1 & \pm 1 \\
\hline 7 & 3 & 1 & 3 & 2 & \pm 1 & \pm 1 \\
\hline 8 & 3 & 2 & 1 & 3 & \pm 1 & \pm 1 \\
\hline 9 & 3 & 3 & 2 & 1 & \pm 1 & \pm 1 \\
\hline
\end{tabular}

Table 2. Actual and coded levels of controlled factors

\begin{tabular}{|c|c|c|c|c|c|c|}
\hline \multirow{3}{*}{ Controlled factors } & \multicolumn{3}{|c|}{ Single jersey knitted fabric } & \multicolumn{3}{|c|}{$1 \times 1$ rib knitted fabric } \\
\hline & \multicolumn{3}{|c|}{ Coded level } & \multicolumn{3}{|c|}{ Coded level } \\
\hline & 1 & 2 & 3 & 1 & 2 & 3 \\
\hline Loop length $\left(X_{1}\right), \mathrm{mm}$ & 6.6 & 7.0 & 7.4 & 5.09 & 5.39 & 5.69 \\
\hline Carriage speed $\left(\mathbf{X}_{2}\right), \mathbf{m s}^{-1}$ & 0.25 & 0.6 & 0.95 & 0.25 & 0.45 & 0.65 \\
\hline Yarn input tension $\left(\mathrm{X}_{3}\right), \mathrm{cN}$ & 6 & 8 & 10 & 6 & 8 & 10 \\
\hline Yarn count $\left(\mathbf{X}_{4}\right), \mathrm{Ne}$ & 5 & 7.5 & 10 & 5 & 7.5 & 10 \\
\hline
\end{tabular}

Table 3. Actual and coded levels of noise factors

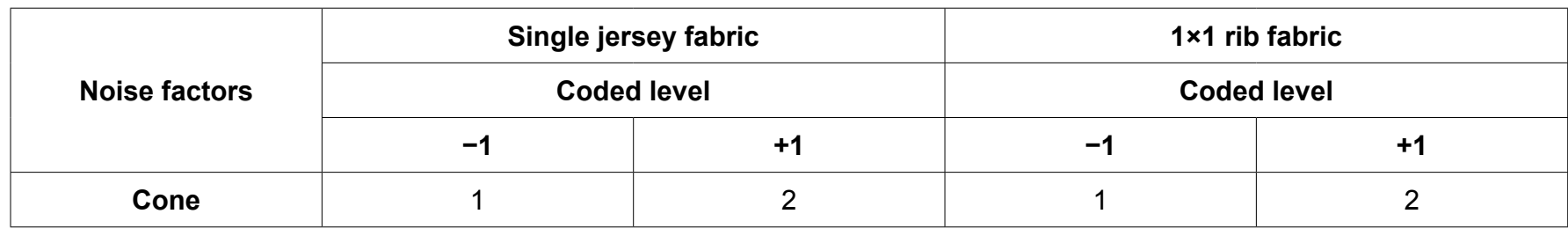




\section{$\underline{2.2 \text { Measurement of structural and comfort parameters }}$}

All the 72 fabric samples (36 single jersey and 36 rib knitted fabrics) were washed in Washcator washing machine as per the EN ISO 6330 for complete relaxation. The samples were conditioned at standard temperature of $20 \pm 2^{\circ} \mathrm{C}$ and $65 \% \pm 4 \%$ relative humidity for 48 hours. Subsequently, the samples were evaluated for fabric thickness, areal density, air permeability, thermal conductivity, and thermal absorptivity. For each of the 72 fabric samples, 10 readings were taken for fabric thickness, areal density, air permeability, thermal conductivity, and thermal absorptivity, and then the average values were calculated.

The fabric structural characteristics such as fabric thickness and areal density (mass per unit area) were evaluated according to the ASTM D1777-96 and ASTM D3776-96 standards, respectively. Air permeability tests of knitted fabrics were conducted according to the ASTM D737 standard using TEXTTEST FX 3300 air permeability tester at a pressure gradient of $100 \mathrm{~Pa}$. Thermal conductivity and thermal absorptivity of fabrics were measured using Alambeta instrument according to the ISO EN 31092 standard. In all cases, the measuring head temperature and contact pressure were approximately $32^{\circ} \mathrm{C}$ and the $200 \mathrm{~Pa}$, respectively. The thermal conductivity of a textile material is its ability to conduct heat through it. Thermal conductivity depends on the material and the porosity [14]. It is expressed as

$$
\text { Thermal conductivity }(\lambda)=\frac{Q h}{A \Delta T t} \quad \mathrm{~W} \mathrm{~m}^{-1} \mathrm{~K}^{-1}
$$

where $Q$ is the quantity of heat conducted $(\mathrm{J}), h$ is the thickness of the material $(\mathrm{m}), A$ is the area of the surface $\left(\mathrm{m}^{2}\right), \Delta T$ is the temperature differential across the material $(\mathrm{K})$, and $t$ is the time (s).

The thermal absorptivity is the measurement of warm-cool feeling of the textile material at first contact of the skin [15]. It is expressed as follows:

$$
\text { Thermal absorptivity }=(\lambda c \rho)^{1 / 2} \mathrm{~W} \mathrm{~s}^{1 / 2} \mathrm{~m}^{-2} \mathrm{~K}^{-1}
$$

where $\lambda$ is the thermal conductivity $\left(\mathrm{W} \mathrm{m}^{-1} \mathrm{~K}^{-1}\right), c$ is the specific heat of the material $\left(\mathrm{J} \mathrm{kg}^{-1} \mathrm{~K}^{-1}\right)$, and $\rho$ is the density of the material $\left(\mathrm{kg} \mathrm{m}^{-3}\right)$. A higher thermal conductivity value indicates higher ability of the material to conduct heat and higher thermal absorptivity means cooler feeling and vice versa [16].

\subsection{Analysis of the response}

The Taguchi method, which uses the design of orthogonal array to study the entire parameter space with small number of experimental run, was used to analyze the responses [1718]. Table 1 shows an orthogonal array, which has four control factors, $X_{1}, X_{2}, X_{3}$, and $X_{4}$, each having three levels. The experimental results are transformed into a signal-to-noise ratio ( $\mathrm{S} / \mathrm{N}$ ratio), which represents the ratio of sensitivity to variability. Maximum S/N ratio signifies minimum effect of random noise factors and vice versa. Therefore, the higher the $\mathrm{S} / \mathrm{N}$ ratio, the better is the quality. The method of calculating the $S / N$ ratio depends on whether the response parameter is "nominal-the- best", "larger-the-better", or "smaller-the-better" and can be calculated using the Equations (3)-(5) [19-21].

(a)

$$
\begin{aligned}
& \text { Nominal-the-best } \\
& \qquad \frac{S}{N}=10 \log \left[\frac{\bar{y}}{s_{y}^{2}}\right]
\end{aligned}
$$

(b)

$$
\begin{aligned}
& \text { Larger-the-better } \\
& \qquad \frac{S}{N}=-10 \log \left[\frac{1}{\mathrm{n}} \sum_{\mathrm{i}=1}^{\mathrm{n}} \frac{1}{\mathrm{y}_{\mathrm{i}}^{2}}\right]
\end{aligned}
$$

$$
\begin{aligned}
& \text { Smaller-the-better } \\
& \qquad \frac{S}{N}=-10 \log \left[\frac{1}{n} \sum_{\mathrm{i}=1}^{\mathrm{n}} \mathrm{y}_{\mathrm{i}}^{2}\right]
\end{aligned}
$$

where, $\bar{y}$ is mean of observed data, $S_{y}{ }^{2}$ is the variance of $y, n$ is the number of experiments in the orthogonal array and $y_{i}$ is the $\mathrm{i}^{\text {th }}$ value measured

In this work, $\mathrm{S} / \mathrm{N}$ ratios of the response parameters, that is, air permeability, thermal conductivity, and thermal absorptivity, have been calculated based on Equation (4) for larger-thebetter. For each significant factor, the level corresponding to the highest $\mathrm{S} / \mathrm{N}$ ratio is the optimum level. The response for $\mathrm{S} / \mathrm{N}$ ratios is an estimate to the rank of significance of the controlled parameters on different comfort properties. An analysis of variance (ANOVA) of the $S / N$ ratio has also been done to determine the percentage contribution of each of the controlled factors on the response parameters.

\section{Results and Discussion}

The experimental results for all the 36 single jersey and $361 \times 1$ rib knitted fabric samples are given in Tables 4 and 5, respectively. It is evident from both Tables 4 and 5 that fabric thickness and areal density of $1 \times 1$ rib knitted fabrics are higher in comparison to single jersey knitted fabrics manufactured in the same gauge knitting machine. The single jersey samples have a thickness range from 1.02 to $1.43 \mathrm{~mm}$ and that for $1 \times 1$ rib knitted fabric is 1.64 to $1.95 \mathrm{~mm}$. The single jersey knitted fabric samples have areal density range from 212.29 to $510.25 \mathrm{~g} \mathrm{~m}^{-2}$, whereas that for $1 \times 1$ rib knitted fabric is from 359.83 to $586.93 \mathrm{~g} \mathrm{~m}^{-2}$.

\subsection{Air permeability}

Experimental results of average air permeability and calculated $\mathrm{S} / \mathrm{N}$ ratios (larger-the-better) for single jersey and $1 \times 1$ rib knitted fabrics are shown in Table 6. It is observed from Table 6 that the maximum $\mathrm{S} / \mathrm{N}$ ratios of air permeability for single jersey and double jersey knitted fabrics are 48.83 and 41.68 , respectively. In case of single jersey knitted fabric, the optimum combinations of parameters that lead to the maximum $\mathrm{S} / \mathrm{N}$ ratio of air permeability are $7.4 \mathrm{~mm}, 0.6 \mathrm{~m} \mathrm{~s}^{-1}, 6 \mathrm{cN}$, and $10 \mathrm{Ne}$ for loop length, carriage speed, input yarn tension, and yarn count, respectively, whereas for $1 \times 1$ rib knitted fabric, the optimum combinations of parameters leading to maximum $\mathrm{S} / \mathrm{N}$ ratio of air permeability are $5.69 \mathrm{~mm}, 0.45 \mathrm{~m} \mathrm{~s}^{-1}, 6 \mathrm{cN}$, and $10 \mathrm{Ne}$ for loop length, carriage speed, input yarn tension, and yarn count, respectively. 
Table 4. Experimental values of structural and comfort properties of single jersey knitted fabric

\begin{tabular}{|c|c|c|c|c|c|c|c|c|c|c|c|}
\hline \multirow[b]{2}{*}{$\begin{array}{l}\text { Sr. } \\
\text { no. }\end{array}$} & \multicolumn{4}{|c|}{ Controlled factors } & \multicolumn{2}{|c|}{ Noise factors } & \multicolumn{5}{|c|}{ Single jersey knitted fabric } \\
\hline & $x$ & $x^{N}$ & $x^{m}$ & $x^{+}$ & ֻัญ & $\stackrel{Ð}{\frac{D}{c}}_{\frac{0}{0}}^{\frac{0}{n}}$ & 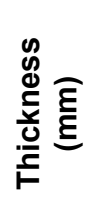 & 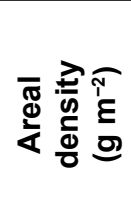 & 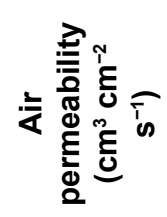 & 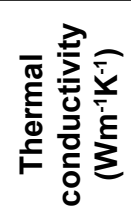 & 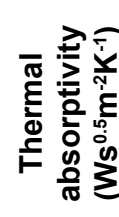 \\
\hline 1 & 1 & 1 & 1 & 1 & -1 & -1 & 1.34 & 490.75 & 39.63 & 46.4 & 136 \\
\hline 2 & 1 & 1 & 1 & 1 & -1 & +1 & 1.32 & 506.50 & 42.45 & 44 & 147 \\
\hline 3 & 1 & 1 & 1 & 1 & +1 & -1 & 1.34 & 495.25 & 41.34 & 45.7 & 141 \\
\hline 4 & 1 & 1 & 1 & 1 & +1 & +1 & 1.33 & 510.25 & 49.29 & 46.1 & 152 \\
\hline 5 & 1 & 2 & 2 & 2 & -1 & -1 & 1.18 & 305.25 & 112.41 & 37.4 & 100.2 \\
\hline 6 & 1 & 2 & 2 & 2 & -1 & +1 & 1.16 & 301.77 & 119.37 & 39 & 108.6 \\
\hline 7 & 1 & 2 & 2 & 2 & +1 & -1 & 1.18 & 309.20 & 107.55 & 39 & 106.4 \\
\hline 8 & 1 & 2 & 2 & 2 & +1 & +1 & 1.17 & 307.80 & 107.02 & 39.8 & 103.2 \\
\hline 9 & 1 & 3 & 3 & 3 & -1 & -1 & 1.02 & 227.70 & 235.1 & 34.8 & 95.8 \\
\hline 10 & 1 & 3 & 3 & 3 & -1 & +1 & 1.02 & 232.50 & 228 & 33.1 & 92 \\
\hline 11 & 1 & 3 & 3 & 3 & +1 & -1 & 1.03 & 224.78 & 238.6 & 36.1 & 91.7 \\
\hline 12 & 1 & 3 & 3 & 3 & +1 & +1 & 1.04 & 235.12 & 228.9 & 33.8 & 96.1 \\
\hline 13 & 2 & 1 & 2 & 3 & -1 & -1 & 1.04 & 215.56 & 279.3 & 34 & 81.1 \\
\hline 14 & 2 & 1 & 2 & 3 & -1 & +1 & 1.08 & 217.12 & 254.3 & 36.3 & 92.6 \\
\hline 15 & 2 & 1 & 2 & 3 & +1 & -1 & 1.07 & 213.87 & 287.6 & 33.8 & 78.5 \\
\hline 16 & 2 & 1 & 2 & 3 & +1 & +1 & 1.08 & 222.54 & 276.9 & 34.5 & 90.8 \\
\hline 17 & 2 & 2 & 3 & 1 & -1 & -1 & 1.33 & 472.34 & 52.62 & 43.6 & 153 \\
\hline 18 & 2 & 2 & 3 & 1 & -1 & +1 & 1.37 & 475.19 & 49.3 & 42 & 137 \\
\hline 19 & 2 & 2 & 3 & 1 & +1 & -1 & 1.38 & 469.94 & 56.71 & 42 & 149 \\
\hline 20 & 2 & 2 & 3 & 1 & +1 & +1 & 1.37 & 478.32 & 48.31 & 43.6 & 129 \\
\hline 21 & 2 & 3 & 1 & 2 & -1 & -1 & 1.15 & 288.55 & 104.25 & 38.2 & 91.6 \\
\hline 22 & 2 & 3 & 1 & 2 & -1 & +1 & 1.17 & 293.22 & 106.55 & 39.4 & 112.9 \\
\hline 23 & 2 & 3 & 1 & 2 & +1 & -1 & 1.16 & 297.34 & 101.07 & 39 & 114.4 \\
\hline 24 & 2 & 3 & 1 & 2 & +1 & +1 & 1.16 & 285.29 & 97.49 & 38.4 & 111.4 \\
\hline 25 & 3 & 1 & 3 & 2 & -1 & -1 & 1.22 & 272.98 & 164.5 & 38.1 & 94.9 \\
\hline 26 & 3 & 1 & 3 & 2 & -1 & +1 & 1.25 & 283.45 & 166.6 & 39.9 & 86.5 \\
\hline 27 & 3 & 1 & 3 & 2 & +1 & -1 & 1.20 & 278.83 & 163.6 & 38.2 & 91.8 \\
\hline 28 & 3 & 1 & 3 & 2 & +1 & +1 & 1.22 & 275.76 & 177.7 & 37.2 & 89.1 \\
\hline 29 & 3 & 2 & 1 & 3 & -1 & -1 & 1.06 & 212.29 & 258.6 & 33 & 72.1 \\
\hline 30 & 3 & 2 & 1 & 3 & -1 & +1 & 1.02 & 218.82 & 283.2 & 32.9 & 76.7 \\
\hline 31 & 3 & 2 & 1 & 3 & +1 & -1 & 1.05 & 223.21 & 275.3 & 34.8 & 76.6 \\
\hline 32 & 3 & 2 & 1 & 3 & +1 & +1 & 1.03 & 216.63 & 291.6 & 32.2 & 72.3 \\
\hline 33 & 3 & 3 & 2 & 1 & -1 & -1 & 1.43 & 446.91 & 62.59 & 42.9 & 121 \\
\hline 34 & 3 & 3 & 2 & 1 & -1 & +1 & 1.42 & 452.26 & 61.8 & 42.3 & 143 \\
\hline 35 & 3 & 3 & 2 & 1 & +1 & -1 & 1.41 & 449.35 & 69.33 & 44.4 & 149 \\
\hline
\end{tabular}


Table 4. Experimental values of structural and comfort properties of single jersey knitted fabric

\begin{tabular}{|c|c|c|c|c|c|c|c|c|c|c|c|}
\hline \multirow[b]{2}{*}{$\begin{array}{l}\text { Sr. } \\
\text { no. }\end{array}$} & \multicolumn{4}{|c|}{ Controlled factors } & \multicolumn{2}{|c|}{ Noise factors } & \multicolumn{5}{|c|}{ Single jersey knitted fabric } \\
\hline & $x^{-}$ & $x^{N}$ & $x^{m}$ & $x^{+}$ & ঠ் & 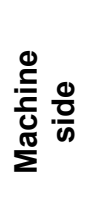 & 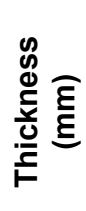 & 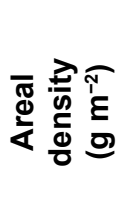 & 츤 & 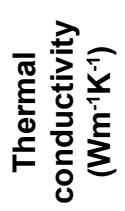 & 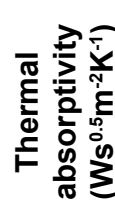 \\
\hline 36 & 3 & 3 & 2 & 1 & +1 & +1 & 1.40 & 439.42 & 70.4 & 39.1 & 110.5 \\
\hline \multicolumn{7}{|c|}{ Mean } & 1.2 & 329.06 & 147.48 & 38.75 & 108.19 \\
\hline \multicolumn{7}{|c|}{ Minimum } & 1.02 & 212.29 & 39.63 & 32.20 & 72.10 \\
\hline \multicolumn{7}{|c|}{ Maximum } & 1.43 & 510.25 & 291.60 & 46.40 & 153.00 \\
\hline \multicolumn{7}{|c|}{ Range } & 0.42 & 297.96 & 251.97 & 14.20 & 80.90 \\
\hline
\end{tabular}

Table 5. Experimental values of structural and comfort properties of $1 \times 1$ rib knitted fabric

\begin{tabular}{|c|c|c|c|c|c|c|c|c|c|c|c|}
\hline \multirow[b]{2}{*}{$\begin{array}{l}\text { Sr. } \\
\text { No. }\end{array}$} & \multicolumn{4}{|c|}{ Controlled factors } & \multicolumn{2}{|c|}{ Noise factors } & \multicolumn{5}{|c|}{$1 \times 1$ rib fabric } \\
\hline & $x^{-}$ & $x^{2}$ & $x^{m}$ & $x^{+}$ & $\stackrel{Ð}{0}$ & 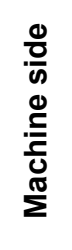 & 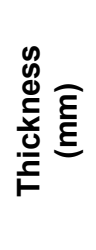 & 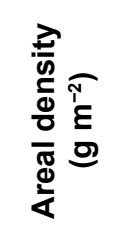 & 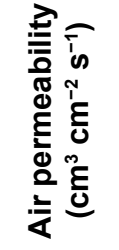 & 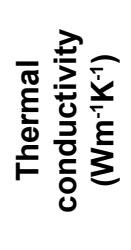 & 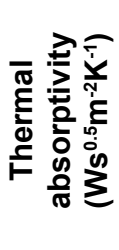 \\
\hline 1 & 1 & 1 & 1 & 1 & -1 & -1 & 1.68 & 578.55 & 14.82 & 74.9 & 197 \\
\hline 2 & 1 & 1 & 1 & 1 & -1 & +1 & 1.68 & 583.43 & 16.75 & 76.2 & 191 \\
\hline 3 & 1 & 1 & 1 & 1 & +1 & -1 & 1.69 & 586.93 & 14.78 & 78.5 & 190 \\
\hline 4 & 1 & 1 & 1 & 1 & +1 & +1 & 1.69 & 582.38 & 11.03 & 78.8 & 201 \\
\hline 5 & 1 & 2 & 2 & 2 & -1 & -1 & 1.78 & 510.35 & 37.56 & 61 & 161 \\
\hline 6 & 1 & 2 & 2 & 2 & -1 & +1 & 1.77 & 516.26 & 34.15 & 61.4 & 154 \\
\hline 7 & 1 & 2 & 2 & 2 & +1 & -1 & 1.78 & 512.23 & 38.95 & 60.6 & 159 \\
\hline 8 & 1 & 2 & 2 & 2 & +1 & +1 & 1.77 & 518.79 & 39.51 & 61.2 & 160 \\
\hline 9 & 1 & 3 & 3 & 3 & -1 & -1 & 1.65 & 422.32 & 77.31 & 47.7 & 121 \\
\hline 10 & 1 & 3 & 3 & 3 & -1 & +1 & 1.65 & 434.21 & 76.45 & 46.8 & 124 \\
\hline 11 & 1 & 3 & 3 & 3 & +1 & -1 & 1.66 & 415.19 & 80.32 & 48.5 & 129 \\
\hline 12 & 1 & 3 & 3 & 3 & +1 & +1 & 1.64 & 405.76 & 84.93 & 47.7 & 127 \\
\hline 13 & 2 & 1 & 2 & 3 & -1 & -1 & 1.70 & 374.2 & 96.17 & 48 & 129 \\
\hline 14 & 2 & 1 & 2 & 3 & -1 & +1 & 1.66 & 377.21 & 97.28 & 48 & 126 \\
\hline 15 & 2 & 1 & 2 & 3 & +1 & -1 & 1.68 & 371.83 & 101.88 & 47.6 & 126 \\
\hline 16 & 2 & 1 & 2 & 3 & +1 & +1 & 1.68 & 376.37 & 102.71 & 43.2 & 119 \\
\hline 17 & 2 & 2 & 3 & 1 & -1 & -1 & 1.81 & 546.76 & 20.16 & 67.4 & 176 \\
\hline 18 & 2 & 2 & 3 & 1 & -1 & +1 & 1.79 & 548.85 & 28.81 & 62.5 & 176 \\
\hline 19 & 2 & 2 & 3 & 1 & +1 & -1 & 1.79 & 543.22 & 16.9 & 56.5 & 171 \\
\hline 20 & 2 & 2 & 3 & 1 & +1 & +1 & 1.75 & 549.32 & 19.96 & 68.1 & 172 \\
\hline 21 & 2 & 3 & 1 & 2 & -1 & -1 & 1.86 & 473.82 & 45.91 & 56.8 & 138 \\
\hline
\end{tabular}


Table 5. Experimental values of structural and comfort properties of $1 \times 1$ rib knitted fabric

\begin{tabular}{|c|c|c|c|c|c|c|c|c|c|c|c|}
\hline \multirow[b]{2}{*}{$\begin{array}{l}\text { Sr. } \\
\text { No. }\end{array}$} & \multicolumn{4}{|c|}{ Controlled factors } & \multicolumn{2}{|c|}{ Noise factors } & \multicolumn{5}{|c|}{$1 \times 1$ rib fabric } \\
\hline & $x$ & $x^{2}$ & $x^{m}$ & $x^{+}$ & さ્さ & 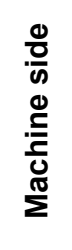 & 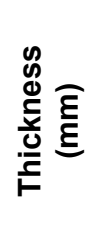 & 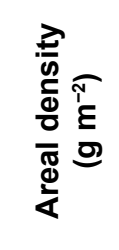 & 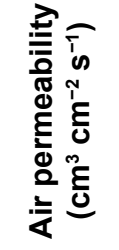 & 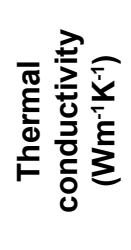 & 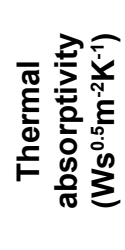 \\
\hline 22 & 2 & 3 & 1 & 2 & -1 & +1 & 1.86 & 478.31 & 46.93 & 56.5 & 139 \\
\hline 23 & 2 & 3 & 1 & 2 & +1 & -1 & 1.85 & 487.63 & 47.6 & 57.7 & 140 \\
\hline 24 & 2 & 3 & 1 & 2 & +1 & +1 & 1.83 & 483.71 & 45.46 & 52.1 & 134 \\
\hline 25 & 3 & 1 & 3 & 2 & -1 & -1 & 1.91 & 481.87 & 49.23 & 46 & 149 \\
\hline 26 & 3 & 1 & 3 & 2 & -1 & +1 & 1.90 & 490.42 & 54.86 & 45.4 & 117 \\
\hline 27 & 3 & 1 & 3 & 2 & +1 & -1 & 1.93 & 487.39 & 50.97 & 46.1 & 138 \\
\hline 28 & 3 & 1 & 3 & 2 & +1 & +1 & 1.91 & 479.74 & 52.48 & 46.7 & 137 \\
\hline 29 & 3 & 2 & 1 & 3 & -1 & -1 & 1.73 & 370.45 & 120.94 & 44.4 & 105 \\
\hline 30 & 3 & 2 & 1 & 3 & -1 & +1 & 1.69 & 381.53 & 118.4 & 44.5 & 102 \\
\hline 31 & 3 & 2 & 1 & 3 & +1 & -1 & 1.70 & 359.83 & 122.73 & 43.8 & 95 \\
\hline 32 & 3 & 2 & 1 & 3 & +1 & +1 & 1.74 & 384.33 & 123.73 & 45.7 & 100 \\
\hline 33 & 3 & 3 & 2 & 1 & -1 & -1 & 1.93 & 534.78 & 24.64 & 55.9 & 159 \\
\hline 34 & 3 & 3 & 2 & 1 & -1 & +1 & 1.95 & 531.85 & 23.64 & 59.9 & 163 \\
\hline 35 & 3 & 3 & 2 & 1 & +1 & -1 & 1.94 & 538.97 & 28.11 & 61.1 & 167 \\
\hline 36 & 3 & 3 & 2 & 1 & +1 & +1 & 1.93 & 541.32 & 26.49 & 58.5 & 158 \\
\hline \multicolumn{7}{|c|}{ Mean } & 1.78 & 479.45 & 55.35 & 55.71 & 145.83 \\
\hline \multicolumn{7}{|c|}{ Minimum } & 1.64 & 359.83 & 11.03 & 43.20 & 95.00 \\
\hline \multicolumn{7}{|c|}{ Maximum } & 1.95 & 586.93 & 123.73 & 78.80 & 201.00 \\
\hline \multicolumn{7}{|c|}{ Range } & 0.32 & 227.10 & 112.70 & 35.60 & 106.00 \\
\hline
\end{tabular}

Table 7 shows the response for $\mathrm{S} / \mathrm{N}$ ratios of air permeability for both single jersey and $1 \times 1$ rib knitted fabrics. It suggests that the yarn count has maximum impact on air permeability followed by loop length, yarn input tension, and carriage speed for single jersey knitted fabric. However, in case of $1 \times 1$ rib knitted fabric, yarn count has maximum impact on air permeability followed by loop length, carriage speed, and yarn input tension. Therefore, yarn count and loop length are the two most dominating factors influencing the air permeability of knitted fabrics irrespective of structure.

Figure 1 depicts the effect of various parameters on $\mathrm{S} / \mathrm{N}$ ratios of air permeability for single jersey and $1 \times 1$ rib knitted fabrics. It is evident from the Figure 1 that for both single jersey and $1 \times 1$ rib knitted fabrics, air permeability increases with the increase in loop length and yarn count. The change in carriage speed and yarn input tension has negligible influence on air permeability.

Table 8 shows the ANOVA summary conducted on S/N ratios on air permeability along with the percentage contribution of different parameters on the response. It is evident from Table
8 that the yarn count is the most dominant factor influencing the air permeability with a contribution of $93.8 \%$ and $92.2 \%$ for single jersey and $1 \times 1$ rib knitted fabrics, respectively. The second dominating factor on air permeability is the loop length, which contributes only $4.5 \%$ and $7.2 \%$ for single jersey and $1 \times 1$ rib knitted fabrics, respectively. This may be ascribed to the fact that the tightness factor of knitted fabrics significantly reduces with the increase in yarn count and loop length. Tightness factor indicates the area covered by the yarn within a repeat area of knitted fabric. The expression of tightness factor for single jersey knitted fabric is as follows:

$$
\text { Tightness factor }=\frac{K_{S}}{l \sqrt{N e}}
$$

where $K s$ is a constant, $I$ is the loop length, and $\mathrm{Ne}$ is the yarn count. As the tightness factor reduces, the knitted fabric becomes more open, and thus it allows easy passage to the air causing increase in air permeability.

Furthermore, it is evident from Table 2 that the percentage change in yarn count from lower to upper level is $100 \%$ (from 5 
Table 6. Average values of air permeability and $\mathrm{S} / \mathrm{N}$ ratios

\begin{tabular}{|c|c|c|c|c|c|c|c|c|}
\hline \multirow[b]{2}{*}{ Exp. no. } & \multirow[b]{2}{*}{$X_{1}$} & \multirow[b]{2}{*}{$X_{2}$} & \multirow[b]{2}{*}{$X_{3}$} & \multirow[b]{2}{*}{$X_{4}$} & \multicolumn{2}{|c|}{ Single jersey knitted fabric } & \multicolumn{2}{|c|}{$1 \times 1$ rib knitted fabric } \\
\hline & & & & & $\begin{array}{c}\text { Average air } \\
\text { permeability } \\
\left(\mathrm{cm}^{3} \mathrm{~cm}^{-2} \mathrm{~s}^{-1}\right)\end{array}$ & $\mathrm{S} / \mathrm{N}$ ratio & $\begin{array}{c}\text { Average air } \\
\text { permeability } \\
\left(\mathrm{cm}^{3} \mathrm{~cm}^{-2} \mathbf{s}^{-1}\right)\end{array}$ & $\begin{array}{c}\mathrm{S} / \mathrm{N} \\
\text { ratio }\end{array}$ \\
\hline 1 & 1 & 1 & 1 & 1 & 43.18 & 32.62 & 14.35 & 22.82 \\
\hline 2 & 1 & 2 & 2 & 2 & 111.59 & 40.93 & 37.54 & 31.45 \\
\hline 3 & 1 & 3 & 3 & 3 & 232.65 & 47.33 & 79.75 & 38.01 \\
\hline 4 & 2 & 1 & 2 & 3 & 274.52 & 48.74 & 99.51 & 39.95 \\
\hline 5 & 2 & 2 & 3 & 1 & 51.74 & 34.23 & 21.46 & 26.16 \\
\hline 6 & 2 & 3 & 1 & 2 & 102.34 & 40.19 & 46.48 & 33.34 \\
\hline 7 & 3 & 1 & 3 & 2 & 168.1 & 44.50 & 51.89 & 34.28 \\
\hline 8 & 3 & 2 & 1 & 3 & 277.17 & 48.83 & 121.45 & 41.68 \\
\hline 9 & 3 & 3 & 2 & 1 & 66.03 & 36.35 & 25.72 & 28.15 \\
\hline
\end{tabular}

Table 7. Response for $\mathrm{S} / \mathrm{N}$ ratios of air permeability

\begin{tabular}{|c|c|c|c|c|c|c|c|c|c|c|}
\hline \multirow{3}{*}{ Factors } & \multicolumn{5}{|c|}{ Single jersey knitted fabric } & \multicolumn{5}{|c|}{$1 \times 1$ rib knitted fabric } \\
\hline & \multicolumn{3}{|c|}{ Average $\mathrm{S} / \mathrm{N}$ ratio } & \multirow{2}{*}{ Range } & \multirow{2}{*}{ Rank } & \multicolumn{3}{|c|}{ Average $\mathrm{S} / \mathrm{N}$ ratio } & \multirow{2}{*}{ Range } & \multirow{2}{*}{ Rank } \\
\hline & Level 1 & Level 2 & Level 3 & & & Level 1 & Level 2 & Level 3 & & \\
\hline $\mathbf{X}_{1}$ & 40.29 & 41.05 & 43.23 & 2.94 & 2 & 30.76 & 33.15 & 34.70 & 3.94 & 2 \\
\hline $\mathbf{X}_{2}$ & 41.95 & 41.33 & 41.29 & 0.66 & 4 & 32.35 & 33.10 & 33.17 & 0.82 & 3 \\
\hline $\mathbf{X}_{3}$ & 40.55 & 42.01 & 42.02 & 1.47 & 3 & 32.61 & 33.18 & 32.82 & 0.57 & 4 \\
\hline $\mathbf{X}_{4}$ & 34.40 & 41.87 & 48.30 & 13.90 & 1 & 25.71 & 33.02 & 39.88 & 14.17 & 1 \\
\hline
\end{tabular}
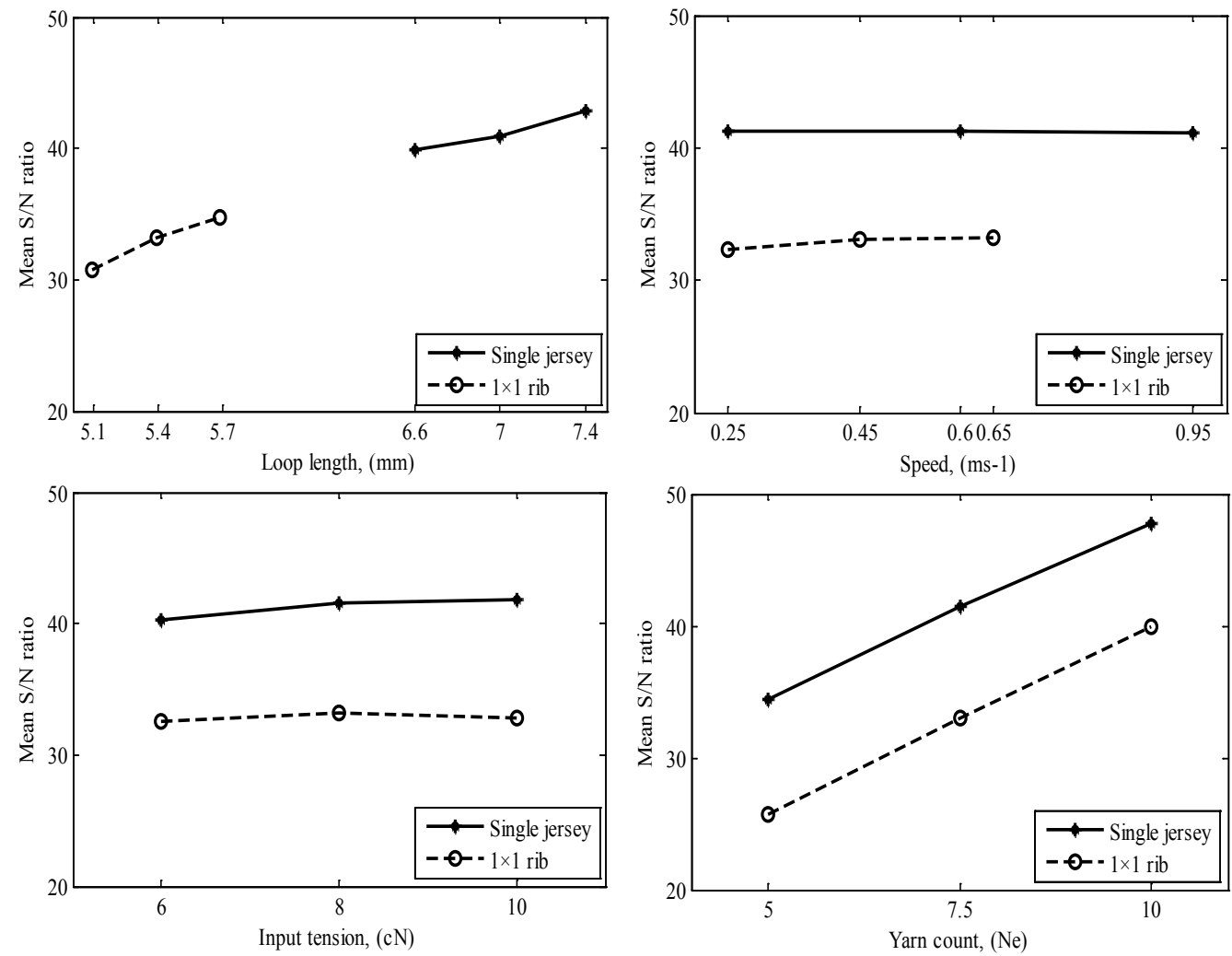

Figure 1. S/N ratio plot of air permeability for single jersey and $1 \times 1$ rib fabric 
Table 8. ANOVA summary conducted on $\mathrm{S} / \mathrm{N}$ ratios of air permeability

\begin{tabular}{|c|c|c|c|c|c|c|c|c|}
\hline \multirow{2}{*}{ Factors } & \multicolumn{4}{|c|}{ Single jersey knitted fabric } & \multicolumn{4}{c|}{ 1×1 rib knitted fabric } \\
\cline { 2 - 9 } & $\begin{array}{c}\text { Sum of } \\
\text { squares }\end{array}$ & $\begin{array}{c}\text { Degree of } \\
\text { freedom }\end{array}$ & $\begin{array}{c}\text { Mean } \\
\text { square }\end{array}$ & $\begin{array}{c}\text { Percentage } \\
\text { contribution }\end{array}$ & $\begin{array}{c}\text { Sum of } \\
\text { squares }\end{array}$ & $\begin{array}{c}\text { Degree of } \\
\text { freedom }\end{array}$ & $\begin{array}{c}\text { Mean } \\
\text { square }\end{array}$ & $\begin{array}{c}\text { Percentage } \\
\text { contribution }\end{array}$ \\
\hline $\mathbf{X}_{1}$ & 13.91 & 2 & 6.96 & 4.5 & 23.70 & 2 & 11.85 & 7.2 \\
\hline $\mathbf{X}_{2}$ & 0.84 & 2 & 0.42 & 0.3 & 1.24 & 2 & 0.62 & 0.4 \\
\hline $\mathbf{X}_{3}$ & 4.31 & 2 & 2.16 & 1.4 & 0.50 & 2 & 0.25 & 0.2 \\
\hline $\mathbf{X}_{4}$ & 290.47 & 2 & 145.24 & 93.8 & 301.38 & 2 & 150.69 & 92.2 \\
\hline Total & 309.53 & 8 & & & 326.82 & 8 & & \\
\hline
\end{tabular}

to $10 \mathrm{Ne}$ ), whereas that for loop length is only around $12 \%$ (from 6.6 to $7.4 \mathrm{~mm}$ for single jersey knitted fabric and from 5.09 to $5.69 \mathrm{~mm}$ for $1 \times 1$ rib knitted fabric). Therefore, the yarn count has emerged as the most dominating factor influencing the air permeability. Yarn input tension and carriage speed have little effect on the air permeability because these two parameters have no significant influence on the fabric tightness factor. As tension variations that arise due to change in yarn tension and carriage speed do not change the loop length through "robbing off" in constant feed knitting, the change in tightness factor is insignificant.

\subsection{Thermal absorptivity and conductivity}

Table 9 shows the experimental results of average thermal absorptivity and calculated $\mathrm{S} / \mathrm{N}$ ratio (larger-the-better), whereas Table 10 shows those for thermal conductivity. Tables 11 and 12 show the response of $\mathrm{S} / \mathrm{N}$ ratio of thermal absorptivity and thermal conductivity, respectively.

It can be seen from Tables 9 and 10 that the largest $\mathrm{S} / \mathrm{N}$ ratio of thermal absorptivity of single jersey and $1 \times 1$ rib knitted fabrics are 43.14 and 45.78 , respectively, and that of thermal conductivity are 33.16 and 37.74 , respectively. For single jersey knitted fabric, the optimum parameters that lead to maximum $\mathrm{S} / \mathrm{N}$ ratio of thermal absorptivity and thermal conductivity are
$6.6 \mathrm{~mm}, 0.25 \mathrm{~m} \mathrm{~s}^{-1}, 6 \mathrm{cN}$, and $5 \mathrm{Ne}$, respectively, for loop length, carriage speed, yarn tension, and yarn count. On the other hand, for $1 \times 1$ rib knitted fabric, the optimum combination of parameters for maximum S/N ratio are $5.09 \mathrm{~mm}, 0.25 \mathrm{~m} \mathrm{~s}^{-1}$, $6 \mathrm{cN}$, and $5 \mathrm{Ne}$, respectively, for loop length, carriage speed, yarn tension, and yarn count.

The response for $\mathrm{S} / \mathrm{N}$ ratios as shown in Tables 11 and 12 suggests that the yarn count has maximum impact on thermal absorptivity and conductivity followed by loop length, carriage speed, and yarn input tension for single jersey knitted fabrics. In case of $1 \times 1$ rib knitted fabric, yarn count has maximum impact on thermal absorptivity and conductivity followed by loop length, yarn input tension, and carriage speed.

Figures 2 and 3 show the effect of various controlled parameters on $\mathrm{S} / \mathrm{N}$ ratio of thermal absorptivity and thermal conductivity, respectively. It is evident from the Figures 2 and 3 that the thermal absorptivity and conductivity decrease with the increase in loop length and yarn count for both types of fabrics, whereas the change in carriage speed and yarn input tension have negligible influence on the thermal properties.

The ANOVA summary conducted on $\mathrm{S} / \mathrm{N}$ ratio of thermal absorptivity and thermal conductivity are tabulated in Tables 13 and 14, respectively, along with the percentage

Table 9. Average values of thermal absorptivity and $\mathrm{S} / \mathrm{N}$ ratios

\begin{tabular}{|c|c|c|c|c|c|c|c|c|}
\hline \multirow[b]{2}{*}{$\begin{array}{c}\text { Experiment } \\
\text { no. }\end{array}$} & \multirow[b]{2}{*}{$X_{1}$} & \multirow[b]{2}{*}{$x_{2}$} & \multirow[b]{2}{*}{$\mathbf{X}_{3}$} & \multirow[b]{2}{*}{$\mathbf{X}_{4}$} & \multicolumn{2}{|c|}{ Single jersey knitted fabric } & \multicolumn{2}{|c|}{$1 \times 1$ rib knitted fabric } \\
\hline & & & & & $\begin{array}{l}\text { Average thermal } \\
\text { absorptivity } \\
\left(\mathbf{W s}^{0.5} \mathbf{m}^{-2} \mathbf{K}^{-1}\right)\end{array}$ & $\mathrm{S} / \mathrm{N}$ ratio & $\begin{array}{l}\text { Average thermal } \\
\text { absorptivity } \\
\left(\mathrm{Wm}^{-1} \mathrm{~K}^{-1}\right)\end{array}$ & $\mathrm{S} / \mathrm{N}$ ratio \\
\hline 1 & 1 & 1 & 1 & 1 & 144 & 43.14 & 194.75 & 45.78 \\
\hline 2 & 1 & 2 & 2 & 2 & 104.6 & 40.38 & 158.5 & 44.0 \\
\hline 3 & 1 & 3 & 3 & 3 & 93.9 & 39.45 & 125.25 & 41.95 \\
\hline 4 & 2 & 1 & 2 & 3 & 85.75 & 38.60 & 125 & 41.93 \\
\hline 5 & 2 & 2 & 3 & 1 & 142 & 42.99 & 173.75 & 44.80 \\
\hline 6 & 2 & 3 & 1 & 2 & 107.57 & 40.52 & 137.75 & 42.78 \\
\hline 7 & 3 & 1 & 3 & 2 & 90.58 & 39.13 & 135.25 & 42.52 \\
\hline 8 & 3 & 2 & 1 & 3 & 74.43 & 37.42 & 100.5 & 40.03 \\
\hline 9 & 3 & 3 & 2 & 1 & 130.88 & 42.14 & 161.75 & 44.17 \\
\hline
\end{tabular}


Table 10. Average values of thermal conductivity and $\mathrm{S} / \mathrm{N}$ ratios

\begin{tabular}{|c|c|c|c|c|c|c|c|c|}
\hline \multirow[b]{2}{*}{$\begin{array}{c}\text { Experiment } \\
\text { no. }\end{array}$} & \multirow[b]{2}{*}{$X_{1}$} & \multirow[b]{2}{*}{$X_{2}$} & \multirow[b]{2}{*}{$X_{3}$} & \multirow[b]{2}{*}{$X_{4}$} & \multicolumn{2}{|c|}{ Single jersey knitted fabric } & \multicolumn{2}{|c|}{$1 \times 1$ rib knitted fabric } \\
\hline & & & & & $\begin{array}{c}\text { Average } \\
\text { thermal } \\
\text { absorptivity } \\
\left(\mathbf{W s}^{0.5} \mathbf{m}^{-2} \mathbf{K}^{-1}\right)\end{array}$ & $\mathrm{S} / \mathrm{N}$ ratio & $\begin{array}{c}\text { Average } \\
\text { thermal } \\
\text { absorptivity } \\
\left(\mathrm{Wm}^{-1} \mathrm{~K}^{-1}\right)\end{array}$ & $\mathrm{S} / \mathrm{N}$ ratio \\
\hline 1 & 1 & 1 & 1 & 1 & 45.55 & 33.16 & 77.1 & 37.74 \\
\hline 2 & 1 & 2 & 2 & 2 & 38.8 & 31.77 & 61.05 & 35.71 \\
\hline 3 & 1 & 3 & 3 & 3 & 34.45 & 30.73 & 47.68 & 33.56 \\
\hline 4 & 2 & 1 & 2 & 3 & 34.65 & 30.78 & 46.7 & 33.36 \\
\hline 5 & 2 & 2 & 3 & 1 & 42.8 & 32.62 & 63.63 & 36.00 \\
\hline 6 & 2 & 3 & 1 & 2 & 38.75 & 31.76 & 55.78 & 34.91 \\
\hline 7 & 3 & 1 & 3 & 2 & 38.35 & 31.67 & 46.05 & 33.26 \\
\hline 8 & 3 & 2 & 1 & 3 & 33.23 & 30.42 & 4.6 & 32.98 \\
\hline 9 & 3 & 3 & 2 & 1 & 42.18 & 32.47 & 58.85 & 35.38 \\
\hline
\end{tabular}

Table 11. Response for $\mathrm{S} / \mathrm{N}$ ratios of thermal absorptivity

\begin{tabular}{|c|c|c|c|c|c|c|c|c|c|c|}
\hline \multirow{3}{*}{ Factors } & \multicolumn{5}{|c|}{ Single jersey knitted fabric } & \multicolumn{5}{|c|}{$1 \times 1$ rib knitted fabric } \\
\hline & \multicolumn{3}{|c|}{ Average $\mathrm{S} / \mathrm{N}$ ratio } & \multirow{2}{*}{ Range } & \multirow{2}{*}{ Rank } & \multicolumn{3}{|c|}{ Average $\mathrm{S} / \mathrm{N}$ ratio } & \multirow{2}{*}{ Range } & \multirow{2}{*}{ Rank } \\
\hline & Level 1 & Level 2 & Level 3 & & & Level 1 & Level 2 & Level 3 & & \\
\hline $\mathbf{X}_{1}$ & 40.99 & 40.70 & 39.56 & 1.43 & 2 & 43.91 & 43.17 & 42.24 & 1.67 & 2 \\
\hline $\mathbf{X}_{2}$ & 40.29 & 40.26 & 40.71 & 0.45 & 3 & 43.41 & 42.94 & 42.97 & 0.47 & 4 \\
\hline $\mathbf{X}_{3}$ & 40.36 & 40.37 & 40.52 & 0.16 & 4 & 42.86 & 43.37 & 43.09 & 0.51 & 3 \\
\hline $\mathbf{X}_{4}$ & 42.76 & 40.01 & 38.49 & 4.27 & 1 & 44.92 & 43.10 & 41.3 & 3.62 & 1 \\
\hline
\end{tabular}

Table 12. Response for $\mathrm{S} / \mathrm{N}$ ratios of thermal conductivity

\begin{tabular}{|c|c|c|c|c|c|c|c|c|c|c|}
\hline \multirow{3}{*}{ Factors } & \multicolumn{5}{|c|}{ Single jersey knitted fabric } & \multicolumn{5}{|c|}{$1 \times 1$ rib knitted fabric } \\
\hline & \multicolumn{3}{|c|}{ Average $\mathrm{S} / \mathrm{N}$ ratio } & \multirow{2}{*}{ Range } & \multirow{2}{*}{ Rank } & \multicolumn{3}{|c|}{ Average $\mathrm{S} / \mathrm{N}$ ratio } & \multirow{2}{*}{ Range } & \multirow{2}{*}{ Rank } \\
\hline & Level 1 & Level 2 & Level 3 & & & Level 1 & Level 2 & Level 3 & & \\
\hline $\mathbf{X}_{1}$ & 31.89 & 31.72 & 31.52 & 0.37 & 2 & 35.67 & 34.76 & 33.88 & 1.79 & 2 \\
\hline $\mathbf{X}_{2}$ & 31.87 & 31.60 & 31.66 & 0.27 & 3 & 34.79 & 34.90 & 34.62 & 0.28 & 4 \\
\hline $\mathbf{X}_{3}$ & 31.78 & 31.68 & 31.67 & 0.11 & 4 & 35.21 & 34.82 & 34.28 & 0.93 & 3 \\
\hline $\mathbf{X}_{4}$ & 32.75 & 31.73 & 30.64 & 2.11 & 1 & 36.37 & 34.63 & 33.30 & 3.07 & 1 \\
\hline
\end{tabular}

contribution of different parameters on the responses. It is evident from the Table 13 that the yarn count is the most dominant factor to influence the thermal absorptivity with a contribution of $88 \%$ and $79.7 \%$ for single jersey and $1 \times 1$ rib knitted fabrics, respectively. The next dominating factor influencing thermal absorptivity is the loop length, which contributes only $10.7 \%$ and $17 \%$ for single jersey and $1 \times 1$ rib knitted fabrics, respectively. Yarn count and loop length decisively influence the tightness factor of the knitted fabric as shown in Equation (6). The thermal absorptivity depends on the tightness factor of the knitted fabric, whereas the thermal conductivity depends on the porosity of the fabric. Higher tightness factor implies more coverage of the fabric surface by the constituent yarns and more possibilities of contact with the hot surface. As a result, the thermal absorptivity increases.

It is noted from Table 14 that the yarn count is the most dominant factor influencing thermal conductivity with a contribution of $95.2 \%$ and $69.4 \%$ for single jersey and $1 \times 1$ rib knitted fabrics, respectively. The contribution of the next dominating factor loop length toward thermal conductivity is $2.9 \%$ and $23.6 \%$ for single jersey and $1 \times 1$ rib knitted fabrics, respectively. The influence of yarn count and loop length on thermal conductivity can be explained by the change in fabric porosity. A fabric may be assumed to be a composite of fiber and air. The thermal 

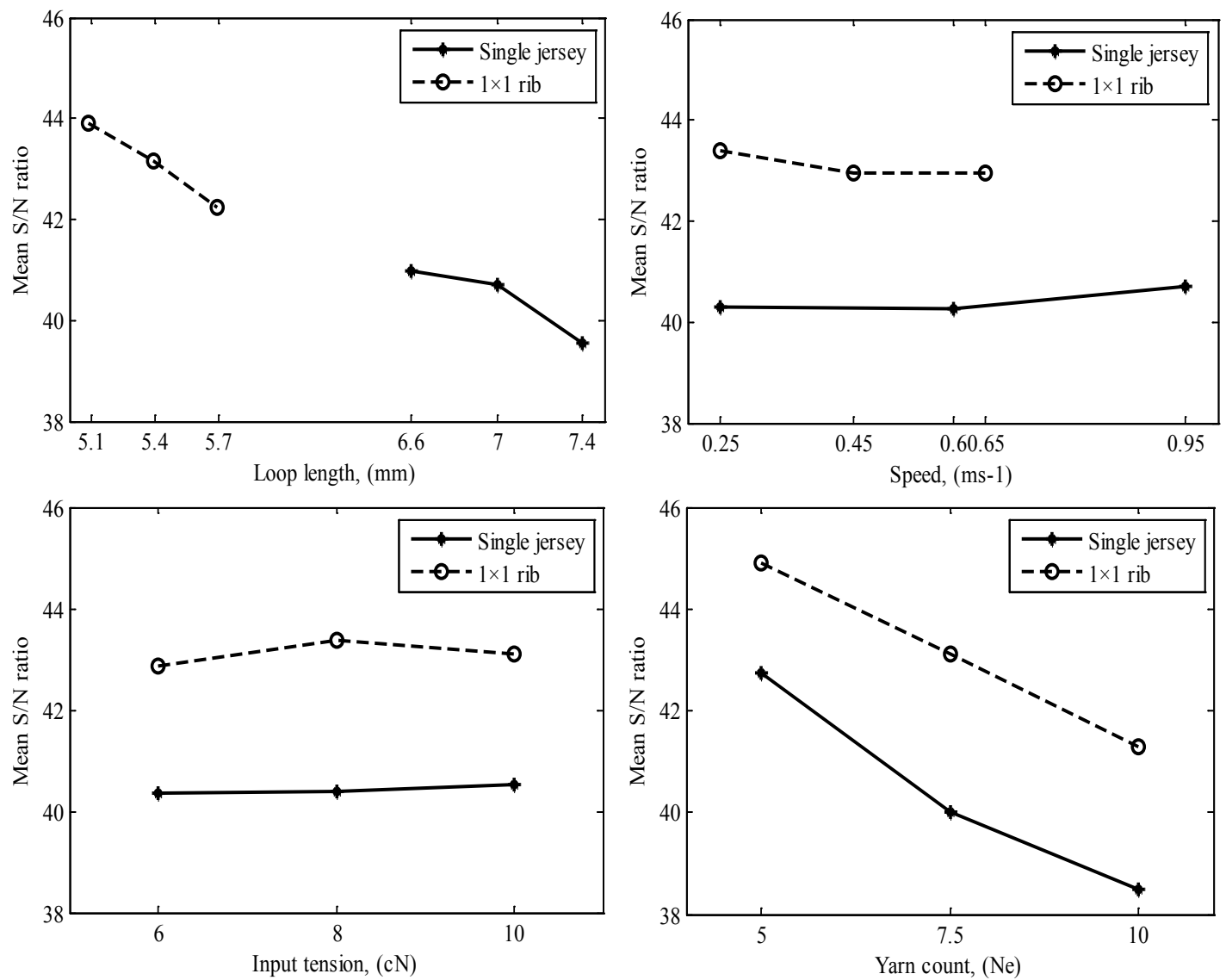

Figure 2. $\mathrm{S} / \mathrm{N}$ ratio plot of thermal absorptivity for single jersey and $1 \times 1$ rib knitted fabrics
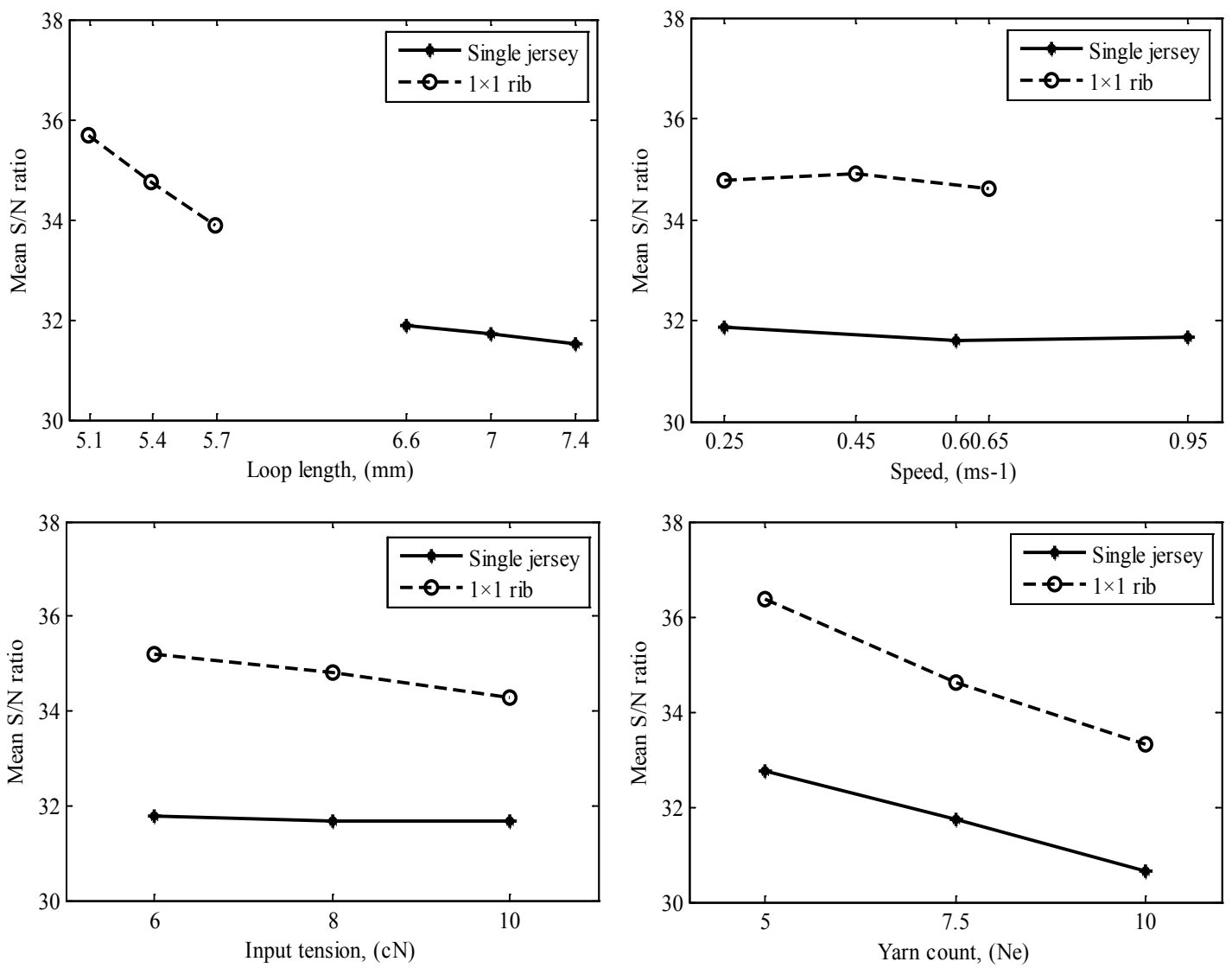

Figure 3. S/N ratio plot of thermal conductivity for single jersey and $1 \times 1$ rib knitted fabrics 
Table 13. ANOVA summary conducted on $\mathrm{S} / \mathrm{N}$ ratios of thermal absorptivity

\begin{tabular}{|c|c|c|c|c|c|c|c|c|}
\hline \multirow{2}{*}{ Factors } & \multicolumn{4}{|c|}{ Single jersey knitted fabric } & \multicolumn{4}{c|}{ 1×1 rib knitted fabric } \\
\cline { 2 - 9 } & $\begin{array}{c}\text { Sum of } \\
\text { squares }\end{array}$ & $\begin{array}{c}\text { Degree of } \\
\text { freedom }\end{array}$ & $\begin{array}{c}\text { Mean } \\
\text { square }\end{array}$ & $\begin{array}{c}\text { Percentage } \\
\text { contribution }\end{array}$ & $\begin{array}{c}\text { Sum of } \\
\text { squares }\end{array}$ & $\begin{array}{c}\text { Degree of } \\
\text { freedom }\end{array}$ & $\begin{array}{c}\text { Mean } \\
\text { square }\end{array}$ & $\begin{array}{c}\text { Percentage } \\
\text { contribution }\end{array}$ \\
\hline $\mathbf{X}_{1}$ & 3.41 & 2 & 1.71 & 10.7 & 4.20 & 2 & 2.10 & 17.0 \\
\hline $\mathbf{X}_{2}$ & 0.37 & 2 & 0.19 & 1.1 & 0.42 & 2 & 0.21 & 1.7 \\
\hline $\mathbf{X}_{3}$ & 0.05 & 2 & 0.03 & 0.2 & 0.38 & 2 & 0.19 & 1.6 \\
\hline $\mathbf{X}_{4}$ & 28.09 & 2 & 14.05 & 88 & 19.62 & 2 & 9.81 & 79.7 \\
\hline Total & 31.92 & 8 & & & 24.62 & 8 & & \\
\hline
\end{tabular}

Table 14. ANOVA summary conducted on $\mathrm{S} / \mathrm{N}$ ratios of thermal conductivity

\begin{tabular}{|c|c|c|c|c|c|c|c|c|}
\hline \multirow{2}{*}{ Factors } & \multicolumn{4}{|c|}{ Single jersey knitted fabric } & \multicolumn{4}{c|}{ 1×1 rib knitted fabric } \\
\cline { 2 - 9 } & $\begin{array}{c}\text { Sum of } \\
\text { squares }\end{array}$ & $\begin{array}{c}\text { Degree of } \\
\text { freedom }\end{array}$ & $\begin{array}{c}\text { Mean } \\
\text { square }\end{array}$ & $\begin{array}{c}\text { Percentage } \\
\text { contribution }\end{array}$ & $\begin{array}{c}\text { Sum of } \\
\text { squares }\end{array}$ & $\begin{array}{c}\text { Degree of } \\
\text { freedom }\end{array}$ & $\begin{array}{c}\text { Mean } \\
\text { square }\end{array}$ & $\begin{array}{c}\text { Percentage } \\
\text { contribution }\end{array}$ \\
\hline $\mathbf{X}_{1}$ & 0.20 & 2 & 0.10 & 2.9 & 4.84 & 2 & 2.42 & 23.6 \\
\hline $\mathbf{X}_{2}$ & 0.12 & 2 & 0.06 & 1.7 & 0.12 & 2 & 0.06 & 0.60 \\
\hline $\mathbf{X}_{3}$ & 0.02 & 2 & 0.01 & 0.3 & 1.32 & 2 & 0.66 & 6.4 \\
\hline $\mathbf{X}_{4}$ & 6.68 & 2 & 3.34 & 95.2 & 14.22 & 2 & 7.11 & 69.4 \\
\hline Total & 7.02 & 8 & & & 20.5 & 8 & & \\
\hline
\end{tabular}

conductivity of a fabric is the combination of the conductivity of air $\left(k_{A}\right)$ and that of the fiber $\left(k_{F}\right)$, and it is expressed as

Fabric thermal conductivity $=\rho k_{A}+(1-\rho) k_{F} \mathrm{~W} \mathrm{~m}^{-1} \mathrm{~K}^{-1}$

where $\rho$ is the fabric porosity. As the conductivity value of air $\left(0.025 \mathrm{~W} \mathrm{~m}^{-1} \mathrm{~K}^{-1}\right)$ is significantly less than that of cotton fiber $\left(\approx 0.2 \mathrm{~W} \mathrm{~m}^{-1} \mathrm{~K}^{-1}\right)$, thus a small change in porosity may lead to a significant change in the thermal conductivity of knitted fabrics. The porosity of a textile fabric can be calculated by the following expression:

Porosity $=\left(1-\frac{\text { Fabric areal density }\left(\mathrm{g} \mathrm{m}^{-2}\right)}{\text { Fabric thickness }(\mathrm{m}) \times \text { Density of fibre }\left(\mathrm{g} \mathrm{m}^{-3}\right)}\right) \times 100$

As the yarn becomes finer, that is, Ne value increases, the areal density and fabric thickness reduce. However, the former reduces at a faster rate as compared to the latter [22]. Thus the porosity increases as the yarn becomes finer. Further, longer loop length increases the fabric porosity. An increase in fabric porosity leads to lower thermal conductivity.

As per the experimental setup, the percentage change in yarn count from lower to upper level is much higher in comparison with that of loop length, the former has more influence than the later on the thermal properties. As the samples were prepared in the knitting machine equipped with "digital control system" to control the loop length, yarn input tension and carriage speed have no significant influence on the tightness factor, areal density, and porosity; hence, they have negligible influence on the thermal properties.

\section{CONCLUSIONS}

This study was intended to find out the significant parameters responsible for the comfort properties of a single jersey and a $1 \times 1$ rib knitted fabrics by considering the two noise factors using the Taguchi method. It was found that the loop length and yarn count have major impacts on air permeability, thermal absorptivity, and thermal conductivity. Higher loop length and finer yarn count increase the air permeability but reduce the thermal conductivity and thermal absorptivity. Also, the optimum levels of these controlled parameters for each response were obtained. The main advantage of the Taguchi design lies in the introduction of noise factors in the experimentation, which is an uncontrolled factor and delivers systematic, simple, and efficient methodology for the optimization of the controlled parameters as well as the ranking of the same with few well-defined experimental sets. Despite the fact that the use of $\mathrm{S} / \mathrm{N}$ ratio is usually perceived as controversial as the $\mathrm{S} / \mathrm{N}$ ratio does not guarantee uncoupling those control factors, which influence the mean, and the control factors that influence the variance yet, the Taguchi approach has several advantages over other methodologies. By combining an inner array of controlled factors with an outer array of noise factors, Taguchi's approach provides full information on control-by-noise interactions. Taguchi argued that such interactions have the greatest importance in achieving a design that is robust to noise factor variation. Also, Taguchi's approach is a "one-shot" experiment with goal being to pick the optimal setting of controlled factors. 


\section{References}

[1] Skenderi, Z., Cubric, I. S., Srdjak, M., (2009). Water Vapour Resistance of Knitted Fabrics under Different Environmental Conditions. Fibres \& Textiles in Eastern Europe, 17, 72-75.

[2] Kotb, N. A., Salman, A. A., Ghazy, H. M., Abu El-Anain, E. H., (2011). Quality of Summer Knitted Fabrics Produced from Microfiber / Cotton Yarns. Journal of Basic and Applied Scientific Research, 1(12), 3416-3423.

[3] Ramachandran, T., Manomani, G., Vigneswaran, C., (2010). Thermal behavior of ring - and compact - spun yarn single jersey, rib and interlock knitted fabrics. Indian Journal of Fibre \& Textile Research, 35, 250-257.

[4] Oglakcioglu, N., Marmarali, A., (2007). Thermal Comfort Properties of Some Knitted Structure. Fibres \& Textiles in Eastern Europe, 15, 94-96.

[5] Chidambaram, P., Govind, R., Venkataraman, K. C., (2011). The Effect of Loop Length and Yarn Linear Density on the Thermal Properties of Bamboo Knitted Fabric. Autex Research Journal, 11(4), 102-105.

[6] Ogulata, R. T., Mavruz, S., (2010). Investigation of Porosity and Air Permeability Values of Plain Knitted Fabrics. Fibres and Textiles in Eastern Europe, 18, 7175.

[7] Onofrei, E., Rocha, A. M., Catarino, A., (2011). The Influence of Knitted Fabrics' Structure on the Thermal and Moisture Management Properties. Journal of Engineered Fibres and Fabrics, 6(4), 10-22.

[8] Ramakrishnan, G., Dhurai, B., Mukhopadhyay, S., (2009). An Investigation into the Properties of Knitted Fabrics made from Viscose Microfibres. Journal of Textile and Apparel, Technology and Management, 6(1), 1-9.

[9] Mavruz, S., Ogulata, R. T., (2010). Optimization of air permeability of interlock knitted fabrics using different experimental design. Proceedings on 7th International Conference, TEXSCl, Liberec, Czech Republic.
[10] Fayala, F., Alibi, H., Benltoufa, S., Jemni, A., (2008). Neural Network for Predicting Thermal Conductivity of Knit Materials. Journal of Engineered Fibres and Fabrics, 3(4), 53-59.

[11] Mitra, A., Majumdar, A., Majumdar, P. K., Banerjee, D., (2013). Predicting thermal resistance of cotton fabrics by artificial neural network model. Experimental Thermal and Fluid Science, 50, 172-177.

[12] Luo, X., Hou, W., Li, Y., Wang, Z., (2007). A fuzzy neural network model for predicting clothing thermal comfort. Computers and Mathematics with Applications, 53, 1840-1846.

[13] Cubric, I. S., Skenderi, Z., Bogdanic, A. M., Andrassy, M., (2012). Experimental study of thermal resistance of knitted fabrics. Experimental Thermal and Fluid Science, 38, 223-228.

[14] Dias, T., Delkumburewatte, G. B., (2008). Changing Porosity of Knitted Structures by Changing Tightness. Fibers and Polymers, 9, 76-79.

[15] Hes, L., (1987). Thermal properties of nonwovens. Proceedings of Congress Index 87, Geneva.

[16] Pac, M. J., Bueno, M. A., Renner, M., (2001). Warm cool feeling relative to tribological properties of fabrics. Textile Research Journal, 71, 806-812.

[17] Park, C. K., Ha, J. Y., (2005). A process for Optimization Sewing Conditions to Minimize Seam Pucker Using the Taguchi Method. Textile Research Journal, 75(3), 245-252.

[18] Singh, S., Shan, H. S., Kumar, P., (2005). Quality and Reliability Engineering Handbook, John Wiley \& Sons.

[19] Zeydan, M., (2008). Modelling the woven fabric strength using artificial neural network and Taguchi methodologies. International Journal of Clothing Science and Technology, 20, 104-118.

[20] Ross, P. J., (1996). Taguchi Techniques for Quality Engineering, McGraw-Hill International Editions.

[21] Taguchi, G., Chowdhury, S., Wu, Y., (2005). Taguchi's Quality Engineering Handbook, John Wiley \& Sons.

[22] Majumdar, A., Mukhopadhyay, S., Yadav, R., (2010). Thermal properties of knitted fabrics made from cotton and regenerated bamboo cellulosic fibres. International Journal of Thermal Sciences, 49, 2042-2048. 